\title{
PReS-FINAL-1011: Can repeated T cell receptor stimulation lead to epigenetic reprogramming of the treg-specific demethylated region in human conventional T cells?
}

\author{
Q Wu $u^{1,2^{*}}, \mathrm{D}$ Bending ${ }^{2}$, LR Wedderburn ${ }^{2}$ \\ From 20th Pediatric Rheumatology European Society (PReS) Congress \\ Ljubljana, Slovenia. 25-29 September 2013
}

\section{Introduction}

Regulatory $\mathrm{T}$ (Treg) cells, vital to prevent autoimmune disease, can be identified by their expression of the forkhead box P3 (FoxP3) transcription factor. Human conventional $\mathrm{T}$ (Tconv) cells stimulated via the $\mathrm{T}$ cell receptor (TCR) can also express FoxP3. Although this can confer some intrinsic regulatory effects, controversy exists over whether FoxP3 expression alone gives rise to the Treg cell phenotype. Treg-specific demethylated region (TSDR) demethylation is thought to be a reliable marker of commitment to the Treg cell lineage. In most human studies, analysis of TSDR methylation status has been performed on bulk populations, where only a subpopulation of cells express FoxP3. However, TSDR demethylation may occur selectively in cells expressing the highest levels of FoxP3 protein. Previously, investigation of epigenetic modifications in $\mathrm{FoxP}^{+}$human Tconv cells has been hampered by the inability to separate cells on the basis of FoxP3 expression. Recently, however, a protocol has been published detailing a method for DNA extraction from cells that have been fixed and stained for FoxP3, permitting more informative phenotyping of TSDR methylation status.

\section{Objectives}

To examine the kinetics and stability of FoxP3 expression in human Tconv cells undergoing repeated TCR stimulation; in addition to analyze the TSDR methylation status on cells separated based on FoxP3 expression.

${ }^{1}$ Imperial College London, London, UK

Full list of author information is available at the end of the article

\section{Methods}

Cells were separated into $\mathrm{CD} 4{ }^{+} \mathrm{CD} 25^{\text {hi }} \mathrm{CD} 127^{\text {lo }}$ (Treg) and $\mathrm{CD} 4{ }^{+} \mathrm{CD} 25^{-} \mathrm{CD} 127^{\text {hi }}$ (Tconv) populations and cultured for 3 weeks with anti-CD3, anti-CD28, cytokine combinations and, in some experiments, demethylating agent 5-azacytidine (5-azaC). At regular intervals, cells were analyzed for expression of Treg cell markers. On days 7 and 16, Tconv cells were sorted into $\mathrm{CD} 4^{+} \mathrm{CD} 25^{+}$ $\mathrm{FoxP}^{+}$and $\mathrm{CD} 4^{+} \mathrm{CD} 25^{+}$FoxP3 $3^{-}$populations for DNA extraction and bisulfite sequencing to analyze TSDR methylation status.

\section{Results}

Activation-induced FoxP3 expression in Tconv cells was augmented by interleukin-2 (IL-2), but was unstable. TSDR became partially demethylated in the day 7 FoxP3 ${ }^{+}$ population in one of two donors. 5-azaC stabilized FoxP3 protein expression and this was associated with a small increase in overall TSDR demethylation.

\section{Conclusion}

FoxP3 protein expression alone may not be an adequate marker of Treg cells in states of chronic stimulation, where a notable proportion of FoxP3-expressing cells may be recently activated Tconv cells. TSDR demethylation may be a more specific marker of commitment to the Treg cell lineage. However, preliminary results suggest a small subpopulation of FoxP3-expressing Tconv cells may demethylate at the TSDR in response to TCR stimulation, warranting further investigation. This work may contribute towards understanding how induced Treg cells could be stably generated in vitro, with 
potential applications in adoptive transfer therapies for the treatment of autoimmune disease.

\section{Disclosure of interest}

None declared.

\section{Authors' details}

${ }^{1}$ Imperial College London, London, UK. ${ }^{2}$ Rheumatology Unit, Institute of

Child Health, University College, London, UK.

Published: 5 December 2013

doi:10.1186/1546-0096-11-S2-P9

Cite this article as: Wu et al:: PReS-FINAL-1011: Can repeated T cell receptor stimulation lead to epigenetic reprogramming of the tregspecific demethylated region in human conventional T cells? Pediatric Rheumatology 2013 11(Suppl 2):P9.

Submit your next manuscript to BioMed Central and take full advantage of:

- Convenient online submission

- Thorough peer review

- No space constraints or color figure charges

- Immediate publication on acceptance

- Inclusion in PubMed, CAS, Scopus and Google Scholar

- Research which is freely available for redistribution

Submit your manuscript at www.biomedcentral.com/submit 